\title{
Investigation of Major Success Factors on Building Construction Projects Management System in Addis Ababa, Ethiopia
}

\author{
Mamaru Dessalegn Belay ${ }^{1}$, Esayas Alemayehu Tekeste ${ }^{2}$, Sintayehu Assefa Ambo ${ }^{3}$ \\ ${ }^{1}$ Department of Civil Engineering, Jimma University, Jimma, Ethiopia \\ ${ }^{2}$ Department of Water Supply and Environmental Engineering, Jimma University, Jimma, Ethiopia \\ ${ }^{3}$ Department of Civil Engineering, Jimma University, Jimma, Ethiopia
}

Email address:

mam.wree@gmail.com (M. D. Belay), esayas16@yahoo.com (E. A. Tekeste), sintayehua9@gmail.com (S. A. Ambo)

\section{To cite this article:}

Mamaru Dessalegn Belay, Esayas Alemayehu Tekeste, Sintayehu Assefa Ambo. Investigation of Major Success Factors on Building Construction Projects Management System in Addis Ababa, Ethiopia. American Journal of Civil Engineering.

Vol. 5, No. 3, 2017, pp. 155-163. doi: 10.11648/j.ajce.20170503.15

Received: January 20, 2017; Accepted: March 1, 2017; Published: April 10, 2017

\begin{abstract}
Major success factors (MSFs) in construction industry are inputs to project management practice which can lead directly or indirectly to project success. Ethiopia is one of the developing countries which cannot achieve its construction project goals due to lack of adherence to different major success factors. This is also true in in the study area of Addis Ababa. The purpose of this study was to investigate major success factors in building construction projects of Addis Ababa. The data collection was conducted using questionnaire, desk review and interview. 120 questionnaires were distributed to 7 contractors, 4 clients, 5 consultants and 2 others companies. From 120 questionnaires, 81 questionnaires were returned back and used for analysis. From 68 identified major management success factors; decision making effectiveness, project delivery system, timely decision by owner/owner's representative, contractor's cash flow, leadership skills of project manager and adequacy of fund are the most significant success factors. Considering results of this research, in order to accomplish building construction projects successfully the management should have effective decision making ability. The project delivery system also has great role for accomplishing building projects successfully.
\end{abstract}

Keywords: Construction Industry, Success, Success Factors, Ranking, Building Construction

\section{Introduction}

The construction industry has been characterized as dynamic in nature as a result the increasing uncertainties in technology, budgets, and development processes. In recent time, building projects are becoming much more complex and require a careful integrated process management tools and techniques [2]

A building project is completed as a result of a combination of many events and interactions, planned or unplanned, over the life of a facility, with changing participants and processes in a constantly changing environment. Certain factors are more critical to project success than others. These factors are called major success factors (MSFs) [1].

Major success factors are the set of circumstances, facts, or influences that contribute to the project success (Hoang, 2008).

Success on a project means that certain expectations for a given participant were met, whether owner, planner, engineer, contractor or operator. However, these expectations may be different for each participant as cited on (Alias, et al., 2014) and the study of project success and major success factors (MSFs) is often considered as one of the vital ways to improve the effectiveness of project delivery (Chan et al., 2004) as cited on [5].

It is widely accepted that project managers need focused efforts to gain an expanded comprehension of the potential effects of the major success factors which in turn could assist their work on current and future projects management. This way, their chances of achieving the project goals could substantially increase in the framework of time, resources, 
and budget constraints [2].

Major success factors (MSFs) may change over time, and may include items such as product quality, employee attitude, manufacturing flexibility, and brand awareness. Major success factors any of the aspects of a business that are identified as vital for successful targets to be reached and maintained. Major success factors are identified in areas as production processes, employee and organization skills, functions, techniques, and technologies [12]

Generally major success factors can be identified from the following six groups of success factor in this study and the detail explanations is discussed under result and discussions part.

1. Management Related Success Factors

2. Purchasing Related Success Factors

3. Client Related Success Factors

4. Contractor Related Success Factors

5. Project Manager Related Success Factors

6. Environment Related Success Factors

\section{Research Questions}

The basic problem of any company is to complete the project with the specified time, cost, scope and quality or with the initial agreement to satisfy the customers by completing the building project successfully. Now the basic questions are:

1) What are the types of success factors for building construction projects management system in Addis Ababa?

2) What are the significant of success factors in building construction projects of Addis Ababa?

3) What are the major success factors in Addis Ababa building construction projects from the perspective of their categories?

\section{Research Objectives}

\subsection{General Objective}

The general objective of this study was to investigate major success factors on building construction projects management system of Addis Ababa.

\subsection{Specific Objective}

The specific objectives of the study are:

1) To investigate the types of success factors on governmental building construction projects management system of Addis Ababa.

2) To rank the types of success factors based on their relative importance index of governmental building projects management system in Addis Ababa.

3) To identify major success factors from the perspective of their categories

\section{Literature Review}

Construction industry is a sector of the economy which is responsible for planning, design, construction, maintenance and eventual demolition of buildings and works [10].

According to a World Bank report (2007) the construction industry is an important sector of the economy and has multiple backward and forward linkages with other sectors. The industry contributes significantly to socio-economic development and employment.

\subsection{Construction Industry in Developing Countries}

In developing countries, the construction industry is a key barometer of economic performance. The construction industry contributes a significant percentage of the gross domestic product (GDP) of the countries and provides employment to a substantial proportion of the working population [9].

Construction industries in all countries face many difficulties and challenges (Gales \& Fellows, 1990; Ofori; 1990) as cited on [9]. However, the problems facing the construction industry in developing countries are significantly more fundamental, more serious and more complex. In developing countries, these difficulties and challenges sit alongside the general situation of socio-economic stress, chronic resource shortages a general inability to deal with the major success factors (Ofori 2000) as cited on [9].

\subsection{Success, Success Criteria and Major Success Factors}

\subsubsection{Success}

The successes of a project as well as the factors that affect this success are considered in a various ways by different project management scholars. There is no unified treatment and definitions of these concepts although there is a consensus about the importance of this aspect for the project management practice. In this respect, Prabhakar (2008) as cited on [6] generalizes that the only agreement is the disagreement on the issue "what is project success".

The literature on major success factors reveals several somewhat conflicting definitions of "project success." The following is a sampling of the various proposals, discussions, and definitions [12].

Success in building construction projects is hazardous matter and might have numerous limitations (factors of failure) and drivers which can lead to successful delivery of a project (factors of success) at the same time. During around half of century researchers in project management field have been working on identification of project success factors. However this area of interest continues to motivate both academician and practitioners to investigate on factors which lead to project success regardless the amount of studies that already have been done [8].

\subsubsection{Success Criteria}

Completion of a construction project within intended budget is frequently seen as a major criterion of project success by clients, contractors, consultants and related stakeholders. It is here that project management becomes essential tool for the delivery of effective projects than the traditional functional management [13]. 


\section{(i) General Project Success Criteria (GPSC) and Project Success Factors (PSF)}

Some PSFs seem to be more significant than others. These criteria and factors are generic and can influence most types of construction projects which are given below [1]

\section{a. Time}

Time is one of the most important project success criteria for any project. Time has been addressed as one of the main criterion by which to evaluate a project's degree of success. It has also been mentioned as a factor, which can help the other factors/criteria to be met. It is found that the definition of time is of great importance. Time as the date when a project is most likely to be completed can be a criteria, but time as a manageable component might be considered as a factor [6].

\section{b. Cost}

Without a doubt, every project is dependent on its cost or budget. Cost has been addressed as a very important success criterion, where as having an intellectual budget plan and proper cost estimation have been mentioned as prominent success factors in some studies.

\section{c. Quality}

Quality, whether it concerns the product or process, has been considered as both a project success criterion and factors. Some researchers named it quality performance and considered it as a major project success criterion. In addition, some other researchers addressed quality as a criterion under the name of product's quality. On the other hand, some researchers considered quality management process as a project success factor, which facilitates the success of other criteria and factors [3].

\section{(ii) Success Criteria According to Owners, Designers and Contractors \\ a. Owner's Criteria}

Owner's criteria for measuring success are: 1. Schedule, 2. Budget, 3. Function for intended use (satisfy users and customers), 4. End result as envisioned 5. Quality (workmanship, products) 6. Aesthetically pleasing 7. Return on investment (responsiveness to audiences), 8. Building must be marketable (image and financial) and 9.Minimize aggravation in producing a building [4]

\section{b. Designer's Criteria}

Designer's criteria for measuring success are: (1) Satisfied client (obtain or develop the potential to obtain repeat work), (2) Quality architectural product, met design fee and profit goal, (3) Professional staff fulfillment (gain experience, learn new skills), (4) Met project budget and schedule, (5) Marketable product/ process (selling tool, reputation with peers and clients), (6) Minimal construction problems (easy to operate, constructible design), (7) socially accepted (community response) $[3,12]$.

\section{c. Contractor's Criteria}

Contractor's criteria for measuring success are: (1) Meet schedule (preconstruction, construction, design),: (2) profit (3) under budget (savings obtained for owner and/or contractor) (4) quality specification met or exceeded (5) no claims (owners, subcontractors) (6) safety (7) client satisfaction (personal relationships) (8) good subcontractor buy out (9) good direct communication (expectations of all parties clearly defined) and (10) minimal or no surprises during the project $[12,14]$.

\section{d. Common Criteria}

Priority item and one that appears in all three lists (designer, owner, and contractor) in some form is the financial reality of doing business. The owner wants the project completed on time and on budget, and the designer and contractor both expect to meet certain profit or fee goals. All three viewpoints also recognize the absence of any legal claims or proceedings on a project as a desirable outcome. In other words, this is a major criterion for measuring success. Another common thread among the three groups involves meeting an appropriate schedule as a way of measuring or determining if a project was successful [10].

\subsubsection{Major Success Factors}

Cooke-Davies, (2002) eliminates a conceptual difference between 'success criteria' and 'success factors'. He stresses that success criteria belong to specific measurement which needs to be formulated in order to conclude whether project succeeds or fails. However, success factors are more about particular levers that can be used by project manager to increase a probability of successful outcome of a project. Project success factors are the elements of a project that can be influenced to increase the likelihood of success; these are independent variable that makes success more likely.

Project success criteria are the measures by which judge the successful outcome of a project; these are dependent variable which measure project success. Successful management factors are those inputs to the management system that lead directly or indirectly to the success of the project or business. Project successful management factors are not universal for all projects since different projects and different people prioritize different sets of success factors. The project implementation process is complex. It usually involves attention to a broad variety of human, budgetary, and technical variables. From project management perspective, major successful management factors (MSFs) are characteristics, conditions, or variables that can have a significant impact on the success of the project when properly sustained, maintained, or managed. There is a very close link between the type and scope of projects and respective Major Successful Management Factors (MSF) [9].

\section{Methodology}

In order to investigate major success factors, this study was performed with two stages. At the first stage to investigate the major success factors questionnaires and interviews were prepared and the questioners distributed 
among the selected projects. The interview was interviewed to some of the client. Then data obtain from the distributed questionnaires and interviewed was analyzed by using the SPSS version 20 and Excel. According to SPSS analysis the largest relative importance index would be in the first rank and this indicates us that factor the first major success factor. The collected data was analyzed up to end of January, 2015.

\section{Result and Discussion}

\subsection{Types of Success Factors on Building Construction Project Management System}

The following factors have been identified from literature reviews and questionnaires as presented in table 1 below

Table 1. Success factors identified through literature review and questionnaires.

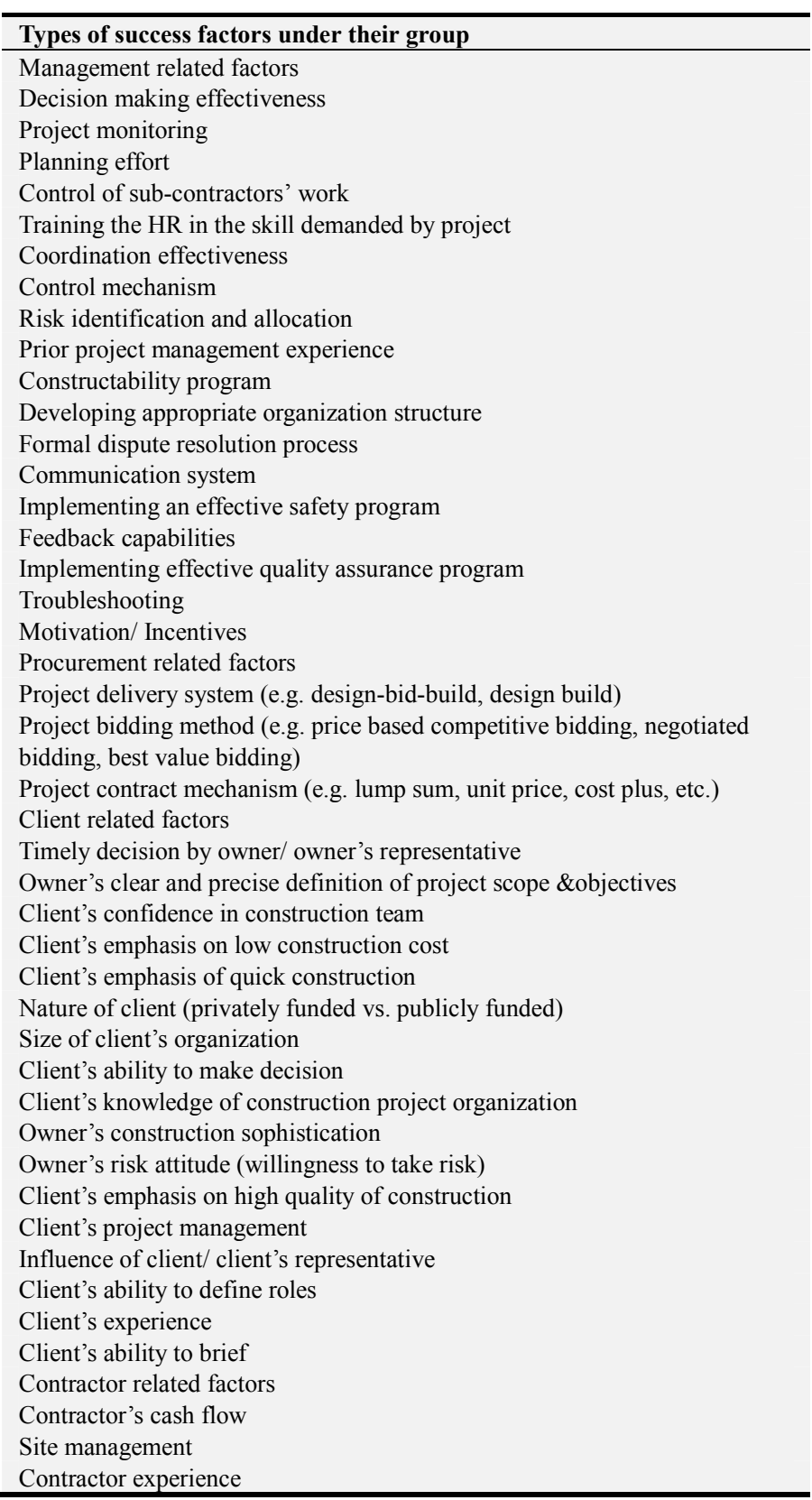

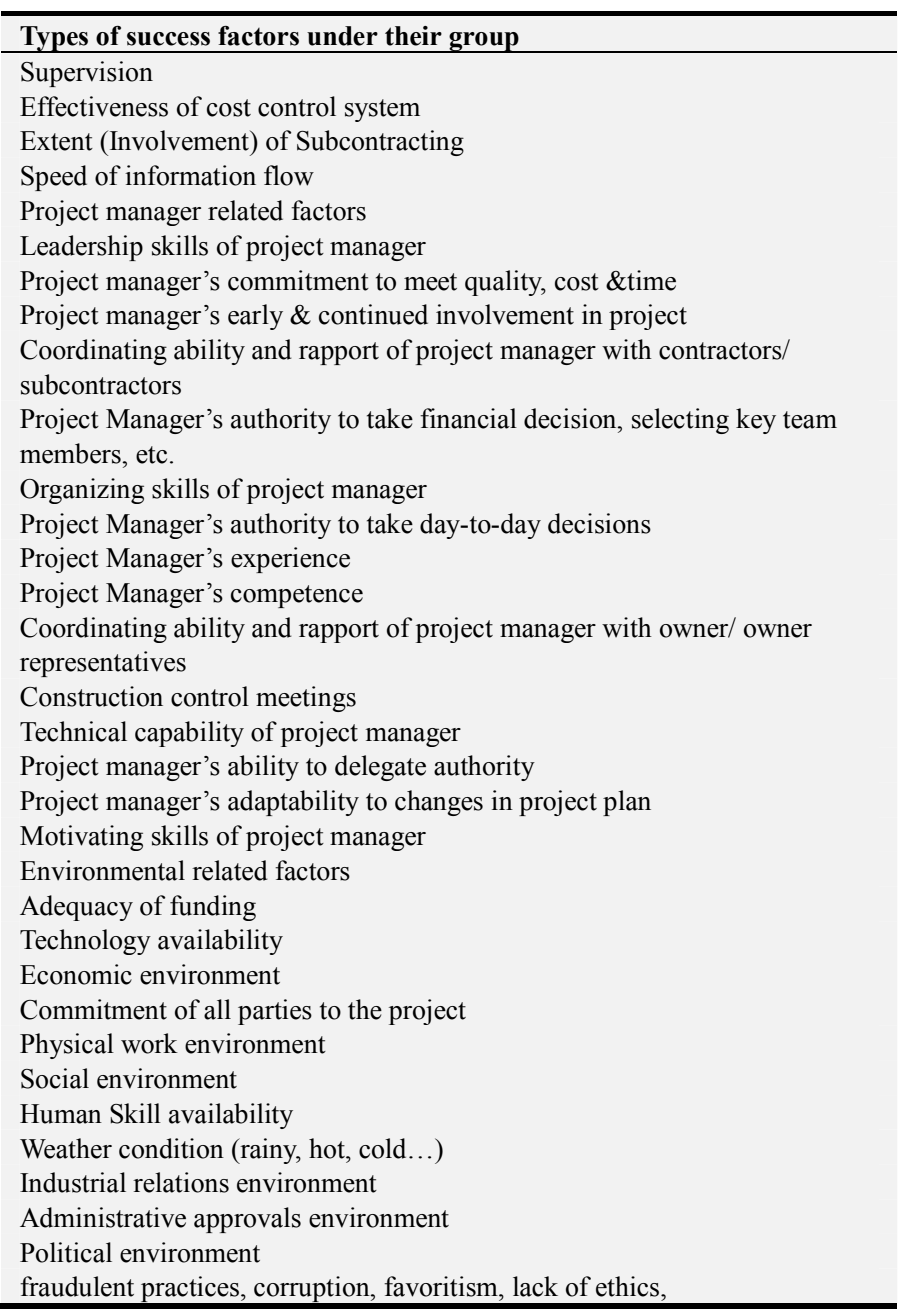

\subsection{Major Success Factors Investigation and Analysis}

\subsubsection{Ranking of Success Factors in Building Construction Projects Based on Their Categories}

Relative importance index

The Relative Importance Index (RII) is a statistical method which is used to determine the ranking of different project success factors. As this survey was designed to investigate the relative importance of various major success factors, the method was adopted in this study within various groups. The RII of Likert five-point scale, ranging from 1 (strongly disagree) to 5 (strongly agree) was adopted and transformed the relative importance indices' for each success factors as follows;

$$
R I I=\frac{\sum W}{A * N}=\frac{1 * n 1+2 * n 2+3 * n 3+4 * n 4+5 * n 5}{5 * N}
$$

Where $\mathrm{w}$ is weighting given to each factor by respondents ranging from 1 to 5 . $\left(\mathrm{n}_{1}=\right.$ number of respondents for strongly dis agree, $\mathrm{n}_{2}=$ number of respondents for disagree, $\mathrm{n}_{3}=$ number of respondents for neutral, $\mathrm{n}_{4}=$ number of respondents for agree, $\mathrm{n}_{5}=$ number of respondents for strongly agree). " $A$ ", is the highest weight (that is 5 in this case), and $\mathrm{N}$ is the total number of respondents. The RII value had a range between $0<\mathrm{RII} \leq 1$. The highest value of RII, the more important success factor and it is the major 
success factors.

The RII was used to rank different success factors. These ranking made it possible to cross compare the relative importance of the factors as perceived by the group of respondents (that is owners, contractors and consultants). Each individual success's RII, as perceived by all respondents was used to assess the general and an overall ranking in order to give an overall picture of major success factors of building construction in Addis Ababa.

The success factors of building construction projects in Addis Ababa were grouped into six categories. These groups were project management factors, procurement related factors, client related factors, contractor-related factors, project manager related factors, and environment related factors. Analyzing of success factors based on their category is essential to take an action on it. Ranking of success factors under the above categories were shown below turn by turn. The success factors under each category were ranked by their relative importance index and discussions on each group of factors were made hereafter.

\section{(i). Management Related Success Factors}

Project management action is a key for project success. Competent project managers can use management tools to plan and execute their construction projects to maximize the project's chances of success. The variables in project management include adequate communication; control mechanisms; feedback capabilities; troubleshooting; coordination effectiveness; decision making effectiveness; monitoring; project organization structure; plan and schedule followed, and related previous management experience; risk identification; formal dispute resolution process; motivation/ incentives; constructability program; training the human resource in the skill demanded by project.
Project managers would have a clear understanding of which aspects of variables might be major for successful project completions. For a project to be successful, it is essential to understand the project requirements right from the start and go for project planning which provides the right direction to project managers and their teams and execute the project accordingly. A successful project is one that is delivered on time and managed within the budget, time, cost and quality have been recognized as "triple constraint" or important elements of project success. The study of project success and major success factors (MSFs) is often considered as one of the vital ways to improve the effectiveness of project delivery. The major success factors (MSFs) are more useful in decision-making support. The study of major success factors (MSFs) is a means of understanding and thereby improving the effectiveness of construction projects.

In order to investigate the major success factors related to project management the responded questionnaires and interviewee was analyzed by using SPSS v20. The following tables indicate the output of the analysis.

As we have seen from table 2 below; decision making effectiveness of a management ( $\mathrm{RII}=0.896$ ) took the first rank, project monitoring $(\mathrm{RII}=0.889)$ took the second rank; Planning effort $(\mathrm{RII}=0.862)$ and Control of sub-contractors' work $(\mathrm{RII}=0.862)$ took the third rank over the other success factors in Addis Ababa building construction projects.

Therefore in the management activity the one who is assigned as a project manager should have the ability of effective decision making, good project monitoring skill, and well project planning ability in order to the project completed successfully.

Table 2. Project management related success factors in Addis Ababa Building construction management system.

\begin{tabular}{|c|c|c|c|c|c|c|c|c|}
\hline Types of success factors & 1 & 2 & 3 & 4 & 5 & Mean & RII & Rank \\
\hline Decision making effectiveness & 2 & 2 & 1 & 26 & 50 & 4.481 & 0.896 & 1 \\
\hline Project monitoring & 2 & 2 & 4 & 23 & 50 & 4.444 & 0.889 & 2 \\
\hline Planning effort & 3 & 1 & 2 & 37 & 38 & 4.309 & 0.862 & 4 \\
\hline Control of sub-contractors' work & 1 & 3 & 8 & 27 & 42 & 4.309 & 0.862 & 4 \\
\hline Training the HR in the skill demanded by project & 1 & 5 & 10 & 21 & 44 & 4.259 & 0.852 & 5 \\
\hline Coordination effectiveness & 2 & 3 & 3 & 38 & 35 & 4.247 & 0.849 & 6 \\
\hline Control mechanism & 3 & 0 & 3 & 44 & 31 & 4.235 & 0.847 & 7 \\
\hline Prior project management experience & 1 & 7 & 10 & 23 & 40 & 4.160 & 0.832 & 9 \\
\hline Constructability program & 2 & 1 & 14 & 32 & 32 & 4.123 & 0.825 & 10 \\
\hline Developing appropriate organization structure & 1 & 3 & 6 & 48 & 23 & 4.099 & 0.820 & 11 \\
\hline Formal dispute resolution process & 1 & 3 & 10 & 46 & 21 & 4.025 & 0.805 & 12 \\
\hline Communication system & 2 & 6 & 10 & 34 & 29 & 4.012 & 0.802 & 13 \\
\hline Implementing an effective safety program & 2 & 6 & 16 & 35 & 22 & 3.852 & 0.770 & 14 \\
\hline Feedback capabilities & 5 & 5 & 10 & 39 & 22 & 3.840 & 0.768 & 15 \\
\hline Motivation/ Incentives & 4 & 12 & 16 & 27 & 22 & 3.630 & 0.726 & 18 \\
\hline
\end{tabular}

\section{(ii). Purchasing Related Success Factors}

A number of researchers identified the importance of procurement factors defined the scope of procurement as the framework within which construction is brought about, acquired or obtained. Therefore, three attributes are used to measure this factor; they are procurement method (selection of the organization for the design and construction of the 
project); tendering method (procedures adopted for the selection of the project team and in particular the main contractor) and project contracting mechanism through which an agreement is performed. The three purchasing related success factors were:

- Project delivery system

- Project Bidding Method

- Project contract mechanism

For a project to be successful a procurement method must be free from bias and should be followed a legal procedure. As the researcher discussed with some of the professional; they said that the winner of the bidding for some projects did not select by following the legal way. Due to this, after the project is awarded to the contractor, the contractor did not do the project according to the agreement and it would lead to unsuccessfulness of the projects. Therefore in order to the project to be successful the procurement method should be in the right way.

As we have seen from the table 3 below the SPSS v20 analysis show the ranks of success factors, based on their relative importance index. The ranking result indicates that project delivery system $(\mathrm{RII}=0.849)$ took first rank; project bidding method $(\mathrm{RII}=0.820)$ took the second rank and project contract mechanism $(\mathrm{RII}=0.802)$ was at the third rank.

Table 3. Procurement system related success factors of building construction projects in Addis Ababa.

\begin{tabular}{|c|c|c|c|c|c|c|c|c|}
\hline Types of success factors & 1 & 2 & 3 & 4 & 5 & Mean & RII & Rank \\
\hline Project delivery system (e.g. design-bid-build, design build) & 0 & 0 & 13 & 35 & 33 & 4.247 & 0.849 & 1 \\
\hline $\begin{array}{l}\text { Project bidding method (e.g. price based competitive bidding, negotiated bidding, } \\
\text { best value bidding) }\end{array}$ & 2 & 1 & 15 & 32 & 31 & 4.099 & 0.820 & 2 \\
\hline Project contract mechanism (e.g. lump sum, unit price, cost plus, etc.) & 6 & 1 & 12 & 29 & 33 & 4.012 & 0.802 & 3 \\
\hline
\end{tabular}

\section{(iii). Client Related Success Factors}

The client or the owner of the project is one party from different parties which are involved in building construction projects. This party is mostly the source of the budget for a project. There are different variables which are under the category of clients. These are the client related variable or success factors concerned with client characteristics, client type and experience, knowledge of construction project organization, project financing, client confidence in the construction team, well-defined scope, owner's risk hate, client project management. By using SPSSv20 there was an analysis and the result of the analysis was as shown in the table 4 .
As we have seen from table 4 below timely decision by owner/ owner's representative $(\mathrm{RII}=0.790)$ took the first rank. Owner's clear and precise definition of project scope and objectives $(\mathrm{RII}=0.785)$ took the second rank client's emphasis on low construction cost, confidence in construction team, emphasis of quick construction $(\mathrm{RII}=0.780)$ took the third rank over the other success factors in Addis Ababa building construction projects.

Generally the client of the project should have a clear objective for what purpose did the building be used after the completion and the client or the owner also should be gave a decision within a short period of time on any type of issue concerning to the project in his or her authority.

Table 4. Clients related success factors of building construction projects in Addis Ababa.

\begin{tabular}{|c|c|c|c|c|c|c|c|c|}
\hline \multirow{2}{*}{ Types of success factors } & \multicolumn{8}{|c|}{ Scale } \\
\hline & 1 & 2 & 3 & 4 & 5 & Mean & RII & Rank \\
\hline Timely decision by owner/owner's representative & 2 & 2 & 18 & 35 & 24 & 3.951 & 0.790 & 1 \\
\hline Owner's clear and precise definition of project scope \&objectives & 4 & 2 & 15 & 35 & 25 & 3.926 & 0.785 & 2 \\
\hline Client's confidence in construction team & 2 & 2 & 19 & 37 & 21 & 3.901 & 0.780 & 3 \\
\hline Client's emphasis on low construction cost & 1 & 9 & 12 & 34 & 25 & 3.901 & 0.780 & 3 \\
\hline Client's emphasis of quick construction & 1 & 4 & 16 & 41 & 19 & 3.901 & 0.780 & 3 \\
\hline Nature of client (privately vs. publicly funded) & 3 & 3 & 23 & 26 & 26 & 3.852 & 0.770 & 4 \\
\hline Size of client's organization & 2 & 2 & 27 & 28 & 22 & 3.815 & 0.760 & 5 \\
\hline Client's ability to make decision & 8 & 0 & 18 & 30 & 25 & 3.79 & 0.758 & 6 \\
\hline Client's knowledge of construction project organization & 3 & 11 & 22 & 13 & 32 & 3.741 & 0.748 & 7 \\
\hline Owner's construction sophistication & 8 & 4 & 18 & 26 & 25 & 3.691 & 0.738 & 8 \\
\hline Owner's risk attitude (willingness to take risk) & 6 & 8 & 12 & 34 & 21 & 3.691 & 0.738 & 8 \\
\hline Client's emphasis on high quality of construction & 8 & 8 & 15 & 23 & 27 & 3.654 & 0.731 & 9 \\
\hline Client's project management & 9 & 3 & 17 & 30 & 22 & 3.654 & 0.731 & 9 \\
\hline Influence of client/ client's representative & 11 & 5 & 12 & 31 & 22 & 3.593 & 0.719 & 10 \\
\hline Client's ability to define roles & 8 & 2 & 26 & 29 & 16 & 3.531 & 0.706 & 11 \\
\hline Client's experience & 10 & 7 & 18 & 26 & 20 & 3.482 & 0.696 & 12 \\
\hline Client's ability to brief & 10 & 3 & 24 & 35 & 9 & 3.37 & 0.674 & 13 \\
\hline
\end{tabular}

\section{(iv). Contractor Related Success Factors}

The main contractor and subcontractors start their main duties when the project reaches the construction stage. The variables included under the contractors were: contractor experience, site management, supervision and involvement of subcontracting, contractor's cash flow, effectiveness of cost control system, and speed of information flow.

The contractor is one of the main parties in any construction industry. The amount of money that is released to the project by the concerned body should be managed properly by the contractor in order to build the construction 
successfully. The contractor should be assigned the knowledgeable guys as an accountant and also it is better if he or she would be a relative to the contractor or responsible citizens to his or her works. The contractor should also have a good site management because if the contractor had a capability of managing the site, it all about resource management and it leads the contractor to accomplish the contract according to an agreement that they made with the owner of the projects and this lead them to successfulness.

As we have seen from table 5 below, contractor's cash flow $(\mathrm{RII}=0.881$ ) took the first rank. Site management $(\mathrm{RII}=0.879)$ took the second rank and contractor experience $(\mathrm{RII}=0.867)$ took the third rank over the other success factors in Addis Ababa building construction projects.

Table 5. Contractor related success factors of building projects in Addis Ababa.

\begin{tabular}{|c|c|c|c|c|c|c|c|c|}
\hline \multirow{2}{*}{ Types of success factors } & \multicolumn{8}{|c|}{ Scale } \\
\hline & 1 & 2 & 3 & 4 & 5 & Mean & RII & Rank \\
\hline Contractor's cash flow & 1 & 2 & 6 & 26 & 46 & 4.407 & 0.881 & 1 \\
\hline Site management & 2 & 1 & 5 & 28 & 45 & 4.395 & 0.879 & 2 \\
\hline Contractor experience & 3 & 1 & 9 & 21 & 47 & 4.333 & 0.867 & 3 \\
\hline Supervision & 1 & 2 & 10 & 33 & 35 & 4.222 & 0.844 & 4 \\
\hline Effectiveness of cost control system & 2 & 4 & 7 & 30 & 38 & 4.210 & 0.842 & 5 \\
\hline Extent (Involvement) of Subcontracting & 2 & 2 & 13 & 28 & 36 & 4.160 & 0.832 & 6 \\
\hline
\end{tabular}

\section{(v). Project Manager Related Success Factors}

The project manager is another main stakeholder in a construction project and his or her competence is a major factor affecting project planning, scheduling, and communication. Variables under this factor consist of the skills and characteristics of project managers, their commitment, competence, experience, and authority. A construction project requires team spirit; therefore team building is important among different parties. Team effort by all parties to a contract, owner, architect, construction manager, contractor, and subcontractors are a crucial ingredient for the successful completion of a project.

Table 6. Project manager related success factors of building projects in Addis Ababa.

\begin{tabular}{|c|c|c|c|c|c|c|c|c|}
\hline \multirow{2}{*}{ Types of Success Factors } & \multicolumn{5}{|c|}{ Scale } & \multirow[b]{2}{*}{ Mean } & \multirow[b]{2}{*}{ RII } & \multirow[b]{2}{*}{ Rank } \\
\hline & 1 & 2 & 3 & 4 & 5 & & & \\
\hline Leadership skills of project manager & 1 & 0 & 3 & 30 & 47 & 4.506 & 0.901 & 1 \\
\hline Project manager's commitment to meet quality, cost \& time & 1 & 2 & 3 & 30 & 45 & 4.432 & 0.886 & 2 \\
\hline Project manager's early \& continued involvement in project & 2 & 0 & 4 & 32 & 43 & 4.407 & 0.881 & 3 \\
\hline Coordinating ability and rapport of project manager with contractors/ subcontractors & 1 & 3 & 5 & 27 & 45 & 4.383 & 0.877 & 4 \\
\hline Project Manager's authority to take financial decision, selecting key team members, etc. & 1 & 1 & 6 & 32 & 41 & 4.370 & 0.874 & 5 \\
\hline Organizing skills of project manager & 1 & 1 & 4 & 37 & 38 & 4.358 & 0.872 & 6 \\
\hline Project Manager's authority to take day-to-day decisions & 3 & 0 & 5 & 35 & 38 & 4.296 & 0.859 & 7 \\
\hline Project Manager's experience & 3 & 1 & 2 & 39 & 36 & 4.284 & 0.857 & 8 \\
\hline Project Manager's competence & 2 & 2 & 6 & 33 & 38 & 4.272 & 0.854 & 9 \\
\hline Coordinating ability and rapport of project manager with owner/ owner representatives & 1 & 2 & 11 & 30 & 37 & 4.235 & 0.847 & 10 \\
\hline Construction control meetings & 1 & 1 & 15 & 27 & 37 & 4.210 & 0.842 & 11 \\
\hline Technical capability of project manager & 1 & 4 & 10 & 29 & 37 & 4.198 & 0.840 & 12 \\
\hline Project manager's ability to delegate authority & 1 & 0 & 9 & 44 & 27 & 4.185 & 0.837 & 13 \\
\hline Project manager's adaptability to changes in project plan & 1 & 6 & 7 & 33 & 34 & 4.148 & 0.830 & 14 \\
\hline Motivating skills of project manager & 1 & 4 & 18 & 30 & 28 & 3.988 & 0.798 & 15 \\
\hline
\end{tabular}

As we have seen from table 6 above after the success factors analyzed by using Excel and SPSS v20 success factors were ranked as shown in table 6. From those ranked success factors leadership skills of project manager $(\mathrm{RII}=0.901)$ took the first rank. Project manager's commitment to meet quality, cost \&time (0.886) took the second rank. Project manager's early \& continued involvement in project $(\mathrm{RII}=0.881)$ took the third rank over the other success factors based on their relative importance indexes.

Project managers should be having the capability of leading the workers in the project. Leading of the workers includes many activities like assigning the right persons to the right place, giving the direction of the work to the workers, encouraging the workers, controlling the quality of construction materials, monitoring the cost of the project, generally controlling the all over activities of the project is the duty of the project managers. Therefore the project manager should be having leading skills to accomplish the project successfully.

\section{(vi). Environment Related Success Factors}

Akinsola et al. (1997), described "environment" as all external influences on the construction process, including social, political, and technical systems. The attributes used to measure this factor are economic environment, social 
environment, political environment, physical environment, industrial relation environment, and level of technology advanced.

Technology is an aspect of the environment that should be considered in developing strategic plans. Political environment is concerned with government policy and the effect of political decisions upon construction projects. The significant roles played by the government in the construction industry are mostly clients, regulators of the national economy, and regulators of the construction environment such as laws that guide ethics and construction practices and many others. This inferred that governments can significantly increase or decrease the demand for construction services through budgetary measures an monetary policies [3].

As we have seen from table 7 below adequacy of fund $(\mathrm{RII}=0.896)$ was the first significant success factors over the others. Technology availability $(\mathrm{RII}=0.859)$ was the second significant success factors and economic environment ( $\mathrm{RII}=0.847$ ) was the third significant success factors over the other in Addis Ababa building construction.

Table 7. Environmental related success factors of building projects in Addis Ababa.

\begin{tabular}{|c|c|c|c|c|c|c|c|c|}
\hline \multirow{2}{*}{ Types of success factors } & \multicolumn{8}{|c|}{ Scale } \\
\hline & 1 & 2 & 3 & 4 & 5 & Mean & RII & Rank \\
\hline Adequacy of funding & 2 & 0 & 5 & 24 & 50 & 4.481 & 0.896 & 1 \\
\hline Technology availability & 2 & 0 & 5 & 39 & 35 & 4.296 & 0.859 & 2 \\
\hline Economic environment & 3 & 1 & 6 & 35 & 36 & 4.235 & 0.847 & 3 \\
\hline Commitment of all parties to the project & 4 & 1 & 4 & 38 & 34 & 4.198 & 0.840 & 4 \\
\hline Physical work environment & 1 & 3 & 5 & 57 & 15 & 4.012 & 0.802 & 5 \\
\hline Social environment & 3 & 0 & 21 & 29 & 28 & 3.975 & 0.795 & 6 \\
\hline Human Skill availability & 4 & 8 & 6 & 33 & 30 & 3.951 & 0.790 & 7 \\
\hline Weather condition (rainy, hot, cold...) & 1 & 5 & 16 & 40 & 19 & 3.877 & 0.775 & 8 \\
\hline Industrial relations environment & 5 & 7 & 11 & 44 & 14 & 3.679 & 0.736 & 10 \\
\hline Administrative approvals environment & 8 & 3 & 15 & 36 & 19 & 3.679 & 0.736 & 10 \\
\hline Political environment & 16 & 1 & 24 & 24 & 16 & 3.284 & 0.657 & 11 \\
\hline $\begin{array}{l}\text { fraudulent practices, corruption, favoritism, lack of } \\
\text { ethics, }\end{array}$ & 45 & 17 & 10 & 6 & 3 & 1.827 & 0.365 & 12 \\
\hline
\end{tabular}

\section{Conclusion}

A number of literatures had been reviewed; a desk review and an interview were conducted to identify success factors of building construction projects in Addis Ababa.

Around 68 types of success factors were identified in Addis Ababa building construction projects. These factors could originate from different six categories of success factors, namely management, procurement, client, contractors, managerial, and environmental group.

The aim of this study was to identify major success factors from the management point of view. Generally based on their occurrences, the type of success factors which can affect building construction management systems were grouped in to six categories as: project management related, procurement related, client related, contractor-related, project manager related, and environmental related success factors. From these different groups of success factors $50 \%$ of top ten highly significance success factors were generated from project manager related success factors while $33.33 \%$ of success factors were from project management and contractor related factors contributed equally. The sources of the remaining $16.67 \%$ of major success factors were environment and client related when we ranked all over success factors.

The top ten major success factors according to their rank order based on relative importance index were the following:

1. Leadership skills of project manager

2. Project clear objective, adequacy of funding, decision making effectiveness

3. Project monitoring;

4. Project manager's commitment to meet quality, cost \&time

5. Project manager's early \& continued involvement in project

6. Contractor's cash flow

7. Site management

8. Coordinating ability and rapport of project manager with contractors/ subcontractors

9. Project Manager's authority to take financial decision, selecting key team members

10. Organizing skills of project manager were the tewelve; top ten major success factor which were identified from success factors analysis.

The above 1-10 lists were the types of major success factors in Addis Ababa building construction projects which were identified in this study according to their order significant.

\section{Acknowledgments}

I consider myself lucky to have had the chance to do my thesis work with Prof. Dr. Ing Esayas Alemayehu and Mr. Sintayehu Assefa. My gratitude and thanks are extended to all project managers, resident engineers, supervisor engineers and others, who have shared their vast experiences gained from extensive years of engineering and construction practices.

\section{References}

[1] Abdelnaser omran, m. A. (2012). An evaluation of the critical success factors for construction projects in libya. Journals of economic behavior, 2, 17-25. 
[2] Addis Ababa city administration integrated land information. (2003). http://www.ilic.gov.et/index.php/en/administrativeboundaries. Retrieved December 30, 2008, from http://www.ilic.gov.et

[3] Akanni, \& Akpomiemie. (2014). Impact of environmental factors on building. Housing and Building National Research Center, 91-97.

[4] Alias, Z., Zawawi, E., Yusof, K., \& Aris. (2014). Determining Critical Success Factors of Project Management. AMER International Conference on Quality of Life (pp. 61 - 69). Malaysia: Centre of Studies for Construction, Faculty of Architecture Planning \& Surveying, Universiti Teknologi MARA, 40450, Shah Alam.

[5] Alexandrova, m. (2012). critical success factors of project management: empirical evidence from projects supported by eu programmes. 9th international asecu conference on (pp. 19). bulgaria: university of national and world economy,sofia, bulgaria.

[6] Alias, Z., Zawawi, E., Yusof, K., \& Aris. (2014). Determining Critical Success Factors of Project Management. AMER International Conference on Quality of Life (pp. $61-69$ ). Malaysia: Centre of Studies for Construction, Faculty of Architecture Planning \& Surveying, Universiti Teknologi MARA, 40450, Shah Alam.

[7] Jari, A. J., Pankaj, \& Bhangale, P. (April 2013). To Study Major Factors Necessary for a Successful Construction Project. International Journal of Innovative Technology and Exploring Engineering (IJITEE), 2(5), 2278-3075.
[8] L. Muhwezi, J. A. (2014). An Assessment of the Factors Causing Delays on Building Construction Projects in Uganda. International Journal of Construction Engineering and Management, 3, 13-23.

[9] Megha, D., \& Rajiv, D. B. (2013). A. Methodology for Ranking of Causes of Delay for Residential Construction Projects in Indian Context. International Journal of Emerging Technology and Advanced Engineering, 396-404.

[10] Pakseresht, A., \& Asgari, G. (December 2012). Determining the Critical Success Factors in Construction Projects. interdisciplinary journal of contemporary research in business, 4(8), 383-393.

[11] Salleh, R. (2009). Critical Success Factors Of Project Management For Brunei Construction Projects:Improving Project Performance. Queensland: School Of Urban Development.

[12] Sanvido, V. (1992). Critical Success Factors For Improving Project Performance, ASCE.

[13] Sugumaran, L. M. (2014). Evaluation of Critical Success Factors In International Journal of Advanced Research in Civil,Structural,Environmental and Infrastructure Engineering and Development, 65-70.

[14] Zewdu, Z. T., \& Aregaw, G. T. (2015). Causes of Contractor Cost Overrun in Construction. International Journal of Business and Economics Research, 4, 180-191. 